\title{
NATURAL RADIOACTIVITY IN DRINKING WATER SOURCES OF THE REPUBLIC OF MOLDOVA
}

\author{
Liuba Corețchi* ${ }^{*}$ Irina Plăvan, Serghei Virlan, Ion Ursulean, Ion Bahnarel
}

National Center of Public Health, Chisinau, Republic of Moldova

\begin{abstract}
Pollution and contamination of drinking water potentially cause severe problems to health so the water quality management addresses both national and international action to assess and prevent associated hazards. A survey to study natural radioactivity in drinking water was carried out in the Republic of Moldova. Approximately 3111 samples of drinking water were analyzed between 1985-1999 and 2011-2015. The samples were categorized according to their origin: bottled or public supply. The samples were analyzed for gross beta, ${ }^{220} \mathrm{Rn},{ }^{222} \mathrm{Rn},{ }^{137} \mathrm{Cs}$ and ${ }^{\circ} \mathrm{Sr}$ activity. The activity concentration for gross beta was found to range from 0.41 to $1.53 \mathrm{~Bq} / \mathrm{L}$. The gross beta activity content in the majority of the samples is due to ${ }^{\circ} \mathrm{K}$. Average concentrations of ${ }^{137} \mathrm{Cs}$ and ${ }^{\circ} \mathrm{Sr}$ activity in the studied waters ranged respectively from 0.02 to $3.2 \mathrm{~Bq} / \mathrm{L}$ and 0.012 to $2.2 \mathrm{~Bq} / \mathrm{L}$. Regarding radon detection, the results showed that the average concentration of radon in artesian wells was $1.93 \mathrm{~Bq} / \mathrm{m}^{3}$; in the aqueduct water - 3.12 $\mathrm{Bq} / \mathrm{m}^{3}$; in the spring waters - $6.17 \mathrm{~Bq} / \mathrm{m}^{3}$; in wells - $3.87 \mathrm{~Bq} / \mathrm{m}^{3}$, in bottled water - o.1 $\mathrm{Bq} / \mathrm{l}$, in mine water - o.93 $\mathrm{Bq} / \mathrm{l}$ and in the surface water - about $1 \mathrm{~Bq} / \mathrm{m}^{3}$. It was stated that ${ }^{222} \mathrm{Rn}$ concentrations in the surveyed waters did not exceed the permissible values according to national rules and Directive 2013/59/EURATOM.
\end{abstract}

Key words: ${ }^{222} \mathrm{Rn},{ }^{137} \mathrm{Cs},{ }^{90} \mathrm{Sr}$, drinking water, radioactivity, radionuclide

DOI: $10.21175 /$ RadProc.2017.23

\section{INTRODUCTION}

Some of the main sources of ${ }^{222} \mathrm{Rn}$ are groundwaters (wells, springs, etc.). Therefore, the use of groundwater with a high concentration of ${ }^{222} \mathrm{Rn}$ may increase the risk of lung and stomach cancer.

Drinking water containing high concentrations of ${ }^{222} \mathrm{Rn}$ would increase the effective dose received by different age groups. It would be also followed by an increased prevalence of lung and stomach cancer development.

According to the European Commission Legislation no. 160 (2016) on radioactive substances in drinking water, local authorities must ensure the supervision of ${ }^{222} \mathrm{Rn}$ concentrations in drinking water that comes from various sources of groundwaters and wells from different geological areas. Surveys of Supervisors should be designed in such way that the parameters that are basic, especially the geology and hydrology of the area, radioactivity of rocks or soil, and type of water source, can be identified and used to take further measures for public exposure to ${ }^{222} \mathrm{Rn}$. Radon concentration monitoring is performed when the determined parametric value of $500 \mathrm{~Bq} / \mathrm{L}$ is exceeded [1]. In the Republic of Moldova, the Fundamental Norms on Radiological Protection (NFRP-2000) establish the norm of ${ }^{222} \mathrm{Rn}$ in drinking water -60 $\mathrm{Bq} / \mathrm{L}$ [2].

The concentration level of ${ }^{222} \mathrm{Rn}$ in water varies within a wide range. In surface waters, concentration levels of ${ }^{222} \mathrm{Rn}$ are generally very low, in the range of several $\mathrm{kBq} / \mathrm{m}^{3}$ [3], while the groundwater concentration of ${ }^{222} \mathrm{Rn}$ is in the range of 1 to $50 \mathrm{kBq} / \mathrm{m}^{3}$ in aquifers and sedimentary rocks at $10-300 \mathrm{kBq} / \mathrm{m}^{3}$ in very deep wells, and from 100 to $50000 \mathrm{kBq} / \mathrm{m}^{3}$ in the crystalline rocks [4]. Increased concentrations of ${ }^{238} \mathrm{U}$ were observed in samples of soil from the surroundings of water containing relatively high concentrations of ${ }^{222} \mathrm{Rn}$ and radium $\left({ }^{226} \mathrm{Ra}\right)$ and calculations of doses from these waters show that a regular use of the water from respective samples presents an additional dose of radiation, up to $4 \mathrm{mSv} /$ year [5].

${ }^{222} \mathrm{Rn}$ concentration measurement in natural waters, such as lakes, springs, wells and groundwater can provide information on hidden deposits of ${ }^{238} \mathrm{U}$. The continuous measurement of ${ }^{222} \mathrm{Rn}$ in drinking water is necessary to protect the general public from health hazards caused by the inhalation of ${ }^{222} \mathrm{Rn}$ [6].

The monitoring of ${ }^{222} \mathrm{Rn}$ in the groundwater of the Northeastern Gran Canaria aquifer was conducted [7]. ${ }^{222} \mathrm{Rn}$ was detected in 28 samples by using a closed loop system, which consists of a monitor AlphaGUARD which measures the concentration of ${ }^{222} \mathrm{Rn}$ in the air through ionization chambers and a set AquaKIT which transfers the dissolved ${ }^{222} \mathrm{Rn}$ in the water sample in contact with the inside air. ${ }^{222} \mathrm{Rn}$ concentrations in the studied water samples ranged between 0.3 to 76.9Bq/L. Spanish legislation on radiological protection limits ${ }^{222} \mathrm{Rn}$ concentration for drinking water to $100 \mathrm{~Bq} / \mathrm{L}$; therefore, the obtained values for the analyzed samples were below this limit. This hydro-geological study reveals a significant correlation between the concentration of ${ }^{222} \mathrm{Rn}$ and material characteristics of the aquifer. Although ${ }^{222} \mathrm{Rn}$ concentrations in the studied samples were below the limit allowed by the law, the authors recommend taking measures to improve drinking water quality.

About 72 samples of the most commonly used bottled waters of Bandar Abbas (Iran) which were collected for 3 consecutive months, May, June and July 2013 were studied [8]. ${ }^{222} \mathrm{Rn}$ concentration was 
measured with RTM1688-2 model. The results showed that the average concentration of ${ }^{222} \mathrm{Rn}$ in the bottled water was $641 \pm 9 \mathrm{~Bq} / \mathrm{m}^{3}$. It has been established that infants received an effective dose higher than children. The largest and smallest effective dose received was by adult men and children, respectively. The average concentration of ${ }^{222} \mathrm{Rn}$ in all types of bottled water has been found to be less than the standard limits set by WHO [9].

An interesting study on ${ }^{222} \mathrm{Rn}$ was conducted in Minabe City (Iran) where ${ }^{222} \mathrm{Rn}$ concentration was measured in the tap water at 5 and $15^{\circ} \mathrm{C}$ [10]. The effective dose was calculated by the equations proposed by UNSCEAR [11]. The geometric average of ${ }^{222} \mathrm{Rn}$ concentration in drinking water was found to be $0.78 \pm 0.06 \mathrm{~Bq} / \mathrm{L}$ and $0.46 \pm 0.04 \mathrm{~Bq} / \mathrm{L}$ to $5^{\circ} \mathrm{C}$ and $15^{\circ} \mathrm{C}$, respectively. The effective doses were 0.006 and $0.003 \mathrm{mSv} /$ year for adults and 0.011 and 0.007 $\mathrm{mSv} /$ year for children, respectively. In addition, the effective dosage for adults from the inhalation of ${ }^{222} \mathrm{Rn}$ to $5^{\circ} \mathrm{C}$ and $15^{\circ} \mathrm{C}$ were respectively estimated to be 0.0021 and $0.0012 \mathrm{mSv} / \mathrm{y}$. The geometric average of ${ }^{222} \mathrm{Rn}$ concentration in drinking water, at temperatures of $5^{\circ} \mathrm{C}$ and $15^{\circ} \mathrm{C}(0.78 \pm 0.06 \mathrm{~Bq} / \mathrm{L}$ and $0.46 \pm 0.04$ $\mathrm{Bq} / \mathrm{L}$ ), is less than the standard limits of EPA [12] and WHO [9]. The authors found that the annual effective dose received by the inhalation and consumption of ${ }^{222} \mathrm{Rn}$ in drinking water is higher in children than in adults. Also, the effective doses in both age groups were much lower than the limits set by the EPA and WHO standards. Increasing of the temperature has reduced the concentration of ${ }^{222} \mathrm{Rn}$ in drinking water, followed by a reduction of the received effective dose. The authors recommended reducing the effective dose of population by the consumption of drinking water at higher temperatures.

Studying the sources that supply the population with drinking water from wells, springs and tap water, high concentrations of ${ }^{222} \mathrm{Rn}$ were found [13], which was still below the admissible norm of $100 \mathrm{~Bq} / \mathrm{l}$, established by the Agency for Environmental Protection of USA (U.S. EPA MCL) [12]. Thus, researchers found high concentrations of ${ }^{222} \mathrm{Rn}$ of 4.6 $\mathrm{Bq} / \mathrm{L}$ and 9.5 Bq/L in springs and wells; and 1.o Bq/L in tap water. Although radon concentrations in studied water sources did not exceed the permissible level of $100 \mathrm{~Bq} / \mathrm{L}$, the authors recommend taking preventive measures to reduce radon concentrations in drinking water that feeds the population.

In the study conducted in China, it was observed that the levels of ${ }^{222} \mathrm{Rn}$ ranged from the detection limit, up to $49 \mathrm{~Bq} / \mathrm{L}$. After the calculation of the geometric and arithmetic average of ${ }^{222} \mathrm{Rn}$ concentrations measured in all samples, the values were set respectively as 5.87 and $4.63 \mathrm{~Bq} / \mathrm{L}$. The annual effective average dose from the inhalation of ${ }^{222} \mathrm{Rn}$ from drinking water was $2.78 \mu \mathrm{Sv}$, and the inhalation of exhaled ${ }^{222} \mathrm{Rn}$ from water was $28.5 \mu \mathrm{Sv}$. The authors concluded that both the intake of ${ }^{222} \mathrm{Rn}$ from drinking water and its inhalation from water have a substantial part on the radiologic danger. Moreover, the authors stated that ${ }^{222} \mathrm{Rn}$ in water is a major concern for public health, especially for consumers who use water directly from wells with an increased concentration of ${ }^{222} \mathrm{Rn}$ [14].
It was demonstrated that the main sources of drinking water in Poland are groundwater supplied from Quaternary, Tertiary, Cretaceous and Jurassic geological formations. ${ }^{222} \mathrm{Rn}$ concentrations were determined in samples of drinking water by the liquid scintillation technique, in the south of Poland. It was demonstrated that the measured values ranged from $0.42 \mathrm{up}$ to $10.52 \mathrm{~Bq} / \mathrm{dm}^{3}$ with the geometric average of $1.92 \mathrm{~Bq} / \mathrm{dm}^{3}$. After calculating the annual average effective doses from water ingestion and inhalation of this radionuclide evaporated from water, the following values were found -1.15 and $11.8 \mu \mathrm{Sv}$, respectively. The authors decided that, in general, the amount of natural radionuclide inhaled from water is not a health hazard, but the inhalation of ${ }^{222} \mathrm{Rn}$ evaporated from water is a substantial part of radiological hazard due to the presence of natural radionuclides formed in the chain disintegration of ${ }^{238} \mathrm{U}$ and thorium in drinking water [15].

\subsection{Geology of the region}

Radon comes from rocks and soils containing ${ }^{238} \mathrm{U}$ and ${ }^{226} \mathrm{Ra}$ but it can also be emitted by certain materials being used in the construction industry. Even drinking water can be contaminated when it flows through rocks that contain ${ }^{222} \mathrm{Rn} .{ }^{222} \mathrm{Rn}$ concentration in the air depends on the amount of ${ }^{238} \mathrm{U}$ in rocks and soil permeability. ${ }^{222} \mathrm{Rn}$ moves slightly in poorly compacted soils. In impermeable soils, this element floats inside the cracks until it reaches the air [16]

${ }^{238} \mathrm{U}$ concentration in the upper crust of the earth is $2.7 \mathrm{mg} / \mathrm{kg}$ [17], with higher concentrations being recorded in granite (typically 2.2 to $6.1 \mathrm{mg} / \mathrm{kg}$ to 300 $\mathrm{mg} / \mathrm{kg}$ ), phosphates $(50-300 \mathrm{mg} / \mathrm{kg}$ ) and organic rich sedimentary rocks like black schist $(3-1250 \mathrm{mg} / \mathrm{kg})$ [18]. Primary uraninite (UO2) mineral is insoluble, but it can be oxidized to $\mathrm{UO}_{2}^{+}-$a more soluble ion in water - rock interaction. The completion of $\mathrm{UO}_{2}{ }^{+}$ carbonate, sulfate or phosphate in solutions can enhance the mobility of $\mathrm{U}$, and high $\mathrm{pH}$ favors the formation of the carbonate complex and desorption of $\mathrm{U}$ (VI) from aquifer sediments containing metal oxides and clay, releasing $U$ in groundwater [19]. U redox potential favors the reduction of U (VI) to U (IV) which is insoluble, thus immobilizing the $\mathrm{U}$ of the water [20]. On the other hand, the primary mechanisms of releasing of ${ }^{222} \mathrm{Rn}$, the most abundant isotope of radon and a degradation product of the series of ${ }^{238} \mathrm{U}-{ }^{234} \mathrm{Th}-$ ${ }^{234} \mathrm{~Pa}-{ }^{234} \mathrm{U}-{ }^{230} \mathrm{Th}-{ }^{226} \mathrm{Ra}$, in groundwater are: dissolution, diffusion and, the most importantly mechanism, the release of the alpha recoil in the rock fractures filled with fluid (Fig. 1) [21].

The appearance of radium in groundwater largely depends on the concentration and distribution of $U$ in aquifer materials, $\mathrm{pH}$ and reduction potential, which influences their absorption in the $\mathrm{Fe}^{-}$or $\mathrm{Mn}$ oxyhydroxide and clay, and their stationary time in groundwater. When $\mathrm{Rn}$ is released into groundwater, its mobility is uncoupled from water organic compounds because of its short lifetime ( 3.82 days for ${ }^{222} \mathrm{Rn}$ ) and because it is a noble gas. Radon distribution depends on the primary source of $U$ in bedrock [22]. Theoretical models, including porosity, U content in rocks, the efficiency of its release, and the density of the rock have been developed to estimate the flow of $\mathrm{Rn}$ from the rock in groundwater [23]. 


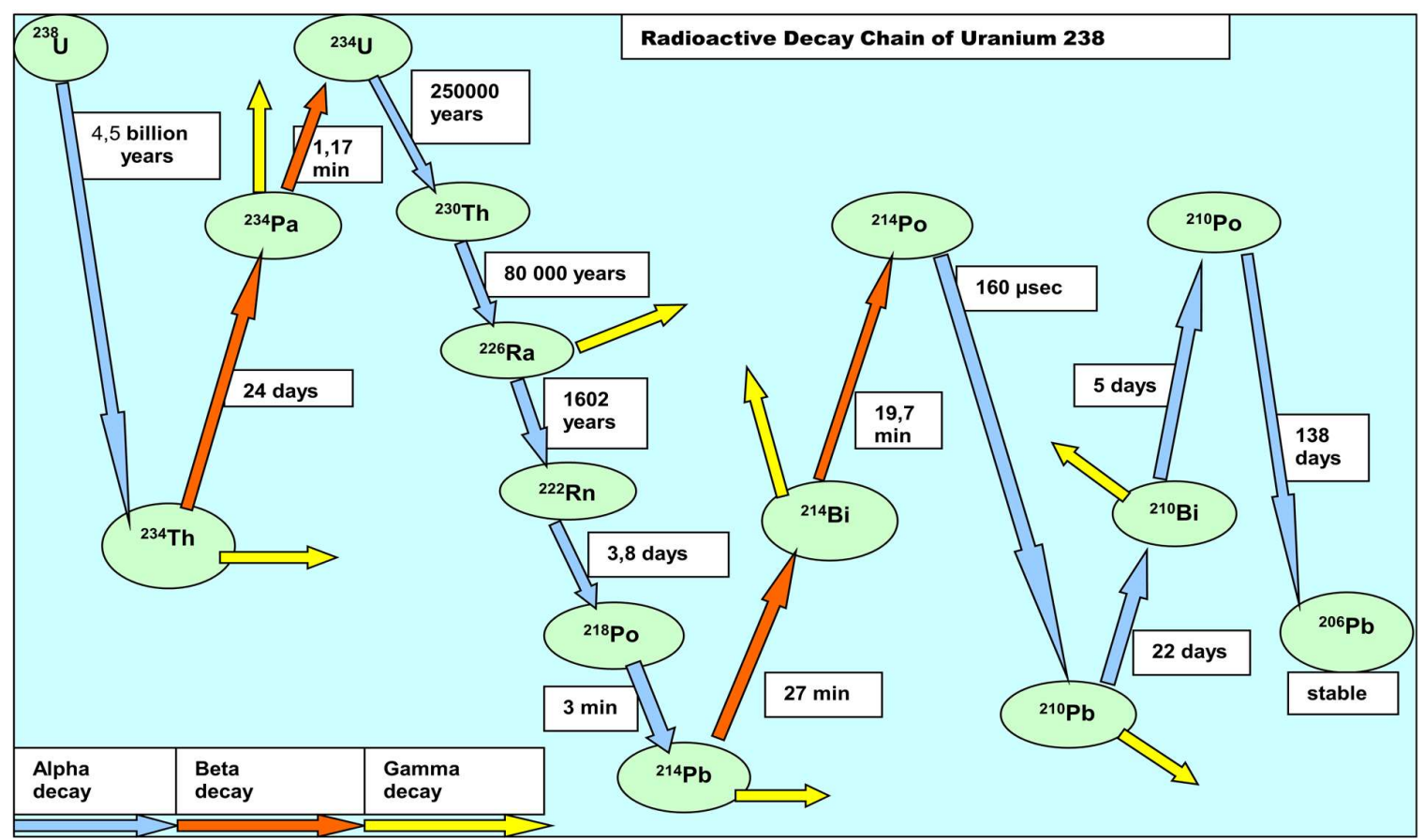

Figure 1. Different types of decay and their half-lives (UNEP, 2016)

The transfer of ${ }^{222} \mathrm{Ra}$ atoms in the soil mineral grain capillaries is also dependent on water from the interstitial pores. When the amount of water in soil is very high, the transport of ${ }^{222} \mathrm{Ra}$ by diffusion is diminished. The diffusion coefficient of radon in water is 1000 times smaller than in the air. In situations where soil moisture is pronounced, the enrichment of soil in radon occurs, decreasing the radon flux to the atmosphere [24].

Over the years, radon, whose atoms migrates into the air of the soil capillaries and then get into the atmosphere, either by diffusion or by transport determined by differences in pressure and exhalation of radon in the atmosphere, has depended on the geological peculiarities and soil characteristics.

\section{Materials AND METHODS}

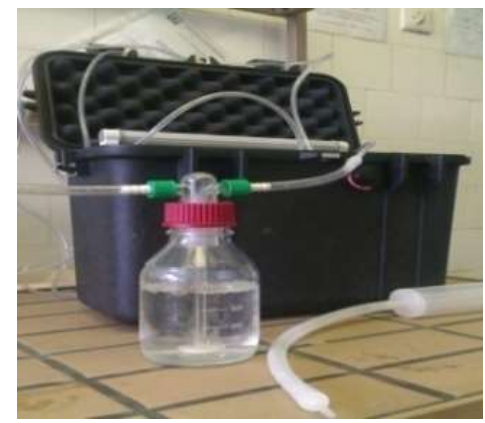

Figure 2. SARAD RTM 1688-2 measuring system for ${ }^{222} \mathrm{Rn}$ in water

Measurements of the radon concentration were performed using the radonometer RTM 1688-2 with an adapter for the determination of ${ }^{222} \mathrm{Rn}$ and ${ }^{220} \mathrm{Rn}$ in water samples; the diapason varied from 1.85 to 9250 Bq/L (Fig. 2).

511 measurements of the radon concentration were performed in 57 different water samples from the main Zones of Moldova during 2012-2014.

The determination of ${ }^{222} \mathrm{Rn}$ concentration was performed by the quantitative analysis of its shortlived decay products using the ionization chamber. Immediately after dissolution $-{ }^{218}$ Po nucleus acquires a positive charge for a short time, because some electrons are released during the emission of alpha particles. Positively charged ions are accumulated under the influence of electric field on the surface of a semiconductor sensor. The number of collected ${ }^{218} \mathrm{Po}$ ions is proportional to the concentration of radon in the inside air of the enclosure. ${ }^{218}$ Po is also an unstable isotope with a half-life of $3.5 \mathrm{~min}$, and the sensor can record only about half of the particles emitted from the decay, which are directed towards the sensor surface. The relationship between recorded ${ }^{222} \mathrm{Rn}$ and ${ }^{218} \mathrm{Po}$ decays can be determined after approximately 5 halfdisintegrations, i.e. after about 15 minutes, which is a minimum ${ }^{222} \mathrm{Rn}$ concentration measurement interval [25].

The gross beta, ${ }^{90} \mathrm{Sr}$ and ${ }^{137} \mathrm{Cs}$ activity was detected using the spectroscopy method in 2220 water samples during 1985-1999 and 2011-2015.

\section{Results AND Discussion}

A particular focus was the study of the radon concentration in the drinking waters of the Republic of Moldova. In order to monitor the radon concentration in drinking water of Moldova, we made 511 measurements in 57 water samples taken from wells, 
artesian wells, water supply (Nistru), spring, and Prut River in different Zones of the country.

The performed radon concentration measurements in the 57 water samples were prelevated from the three zones of the country: North, South and Center. The results show that the highest concentrations of radon have been recorded in the North zone of the country, followed by the Central zone with $2.84 \mathrm{~Bq} / \mathrm{L}$. The lowest concentrations of radon were recorded in the South zone with the average of $1.09 \mathrm{~Bq} / \mathrm{L}$.

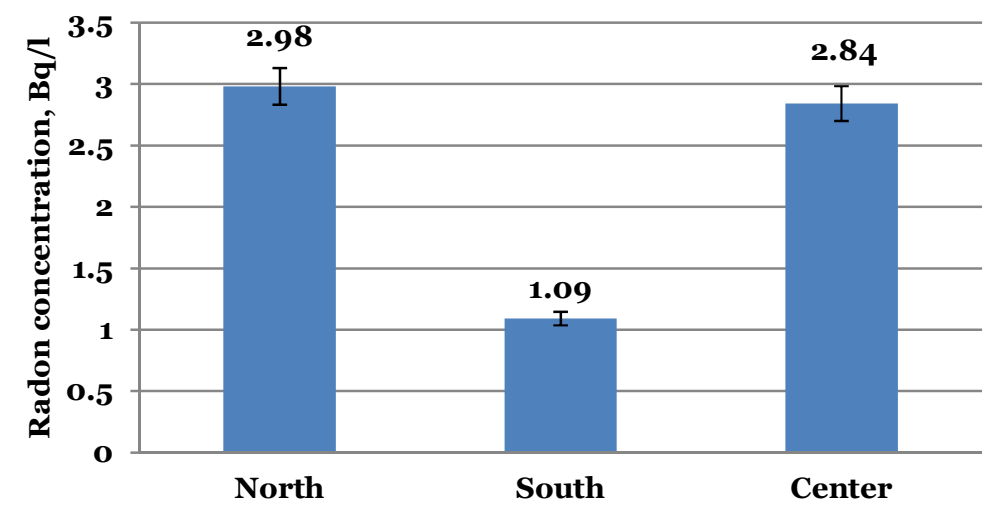

Figure 3. The average values of radon concentration in different drinking water sources in the North, South and Center in the 2012-2014 period

Regarding the type of water source, the results show that the highest concentration of radon was recorded in spring waters $-6.17 \mathrm{~Bq} / \mathrm{L}$ followed by well waters, aqueducts and artesian wells. Lower concentrations of radon were recorded in surface water, mine wells and bottled waters.

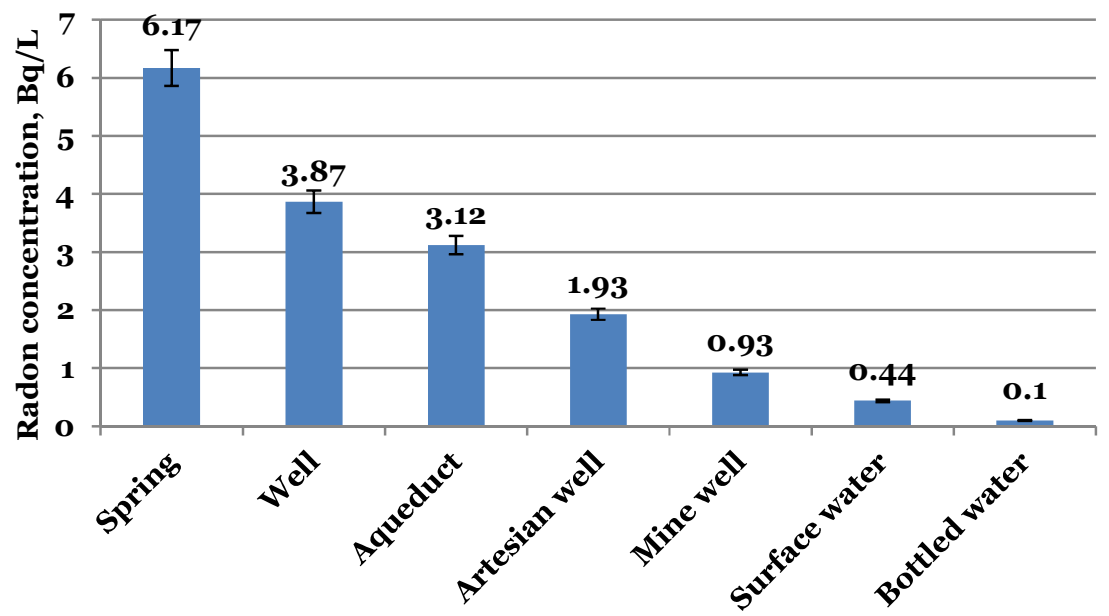

Figure 4. The average values of radon concentrations in various drinking water sources in the 2012-2014 period

At the same time, it has been found that the concentration of radon in water varied, depending on the weather conditions. Thus, in 2012, the variability of radon in water was $0.082-11.38 \mathrm{~Bq} / \mathrm{L}$, in $2013-0.059-$ 6.648 and in $2014-0.082-11.385 \mathrm{~Bq} / \mathrm{L}$ (Table 1).

Table 1. Variability of the ${ }^{222} \mathrm{Rn}$ concentration in waters of the Republic of Moldova during the 2012-2014 period

\begin{tabular}{|c|l|l|l|l|c|}
\hline \multicolumn{3}{|c|}{$\begin{array}{c}\text { Number of } \\
\text { measurements }\end{array}$} & \multicolumn{3}{c|}{$\begin{array}{c}\text { Variation limits of the } \mathrm{Rn}^{222} \\
\text { concentration, } \mathrm{Bq} / \mathrm{L}\end{array}$} \\
\hline 2012 & 2013 & 2014 & 2012 & 2013 & 2014 \\
\hline 380 & 113 & 18 & $\begin{array}{c}0.082- \\
11.38\end{array}$ & $\begin{array}{c}0.059- \\
6.648\end{array}$ & $\begin{array}{c}0.082- \\
11.385\end{array}$ \\
\hline
\end{tabular}

So, higher concentrations of ${ }^{222} \mathrm{Rn}$ were found for well waters and spring waters. This shows that, at deeper depths, radon accumulation is enhanced and it penetrates the water by tectonic cracks.

It should also be mentioned that radon concentrations in the investigated waters have not exceeded the allowable values according to the national [2] and European Council Directive 2013/59/Euratom [26].

In order to study the consequences of the Chernobyl nuclear accident, the content of radionuclides in 2220 samples of surface waters during 1985-1999, i.e. up to and after the accident, has been 
investigated. The results show that the concentration of studied radionuclides suffered changes, as evidenced by their increased values in the first days after the accident (Table 2). It was demonstrated that, in May and June 1986, the gross beta was $764 \pm 111$ and 477.3 \pm 86 , respectively. At the same time, the concentration of ${ }^{90} \mathrm{Sr},{ }^{137} \mathrm{Cs}$ and ${ }^{131} \mathrm{I}$ in May was: $2.2 \pm 0.01 ; 3.03 \pm 0.01$; $30.7 \mathrm{~Bq} / \mathrm{L}$ and in June: $0.09 \pm 0.01 ; 0.16 \pm 0.01$ and 11.1 $\mathrm{Bq} / \mathrm{L}$. Beginning with July, these values were in diminishing.

Table 2. Variability of the content of radionuclides in surface waters

\begin{tabular}{|c|c|c|c|c|}
\hline \multirow[t]{2}{*}{ Period } & \multicolumn{4}{|c|}{ The concentrations of radionuclides, Bq/L } \\
\hline & Gross beta & ${ }^{90} \mathrm{Sr}$ & ${ }^{137} \mathrm{Cs}$ & ${ }^{131} \mathrm{I}$ \\
\hline 1985 & $0.56 \pm 0.06$ & $0.01 \pm 0.001$ & - & - \\
\hline 1986 before CNA & $0.41 \pm 0.07$ & $0.02 \pm 0.001$ & $0.02 \pm 0.01$ & - \\
\hline 1986, May & $764 \pm 111$ & $2.2 \pm 0.01$ & $3.03 \pm 0.01$ & 30.7 \\
\hline 1986, June & $477 \cdot 3 \pm 86$ & $0.09 \pm 0,01$ & $0.16 \pm 0.01$ & 11.1 \\
\hline 1986, July & $1.53 \pm 0.01$ & $0.08 \pm 0.01$ & $0.12 \pm 0.01$ & - \\
\hline 1986, August-December & $0.77 \pm 0.01$ & $0.06 \pm 0.01$ & $0.17 \pm 0.03$ & - \\
\hline 1987 & $0.54 \pm 0.2$ & $0.05 \pm 0.02$ & $0.06 \pm 0.02$ & - \\
\hline 1990 & $0.48 \pm 0.16$ & $0.04 \pm 0.01$ & $0.04 \pm 0.01$ & - \\
\hline 1999 & $0.61 \pm 0.15$ & $0.016 \pm 0.04$ & $0.05 \pm 0.012$ & - \\
\hline
\end{tabular}

Natural and artificial radioactivity in drinking water in Moldova was also studied during the period 2011-2015. The results show that the radionuclide content did not exceed the norms stipulated in national regulation (Table 3 ).

Table 3. Radionuclides activity in drinking water in the Republic of Moldova during 2011-2015

\begin{tabular}{|c|c|c|c|c|c|c|c|c|c|c|c|}
\hline \multirow{2}{*}{$\begin{array}{c}\text { Radionuclide } \\
\text { activity, } \\
\text { Bq/L }\end{array}$} & \multicolumn{2}{|c|}{2011} & \multicolumn{2}{|c|}{2012} & \multicolumn{2}{|c|}{2013} & \multicolumn{2}{|c|}{2014} & \multicolumn{2}{|c|}{2015} & \multirow{2}{*}{$\begin{array}{c}\text { National } \\
\text { allowable } \\
\text { levels, } \\
\text { Bq/L }\end{array}$} \\
\hline & $\max$ & $\min$ & $\max$ & $\min$ & $\max$ & $\min$ & $\max$ & $\min$ & $\max$ & $\min$ & \\
\hline $137 \mathrm{Cs}$ & 1.5 & O & 2.19 & $<1.5$ & 3.2 & $<1.5$ & 2.14 & $<1.5$ & 2.0 & $<1.5$ & 8.0 \\
\hline${ }^{90} \mathrm{Sr}$ & 0.7 & O & 0.7 & $<0.7$ & 1.18 & $<0.7$ & 0.7 & $<0.7$ & 0.7 & $<0.7$ & 8.0 \\
\hline
\end{tabular}

\section{CONCLUSiOns}

This is the first detailed study of radionuclide concentration in drinking water from Moldova in relation with the implementation of the Council Directive 2013/59/EURATOM of 5 December 2013. It was demonstrated that the water radon concentration varies widely and it depends on the nature of the aquifer, namely, the preventing lithology and weather conditions. Radon concentrations measured in all studded localities were found to be lower than the minimum standard set by the World Health Organization. The highest concentration of ${ }^{222} \mathrm{Rn}$ was recorded in small aquifers in spring water and wells, and the lowest concentration in large aquifers - in surface waters due to direct transition of ${ }^{222} \mathrm{Rn}$ in the air.

The results show that the water radionuclide content did not exceed the norms stipulated in national regulation. It was detected that, after the Chernobyl

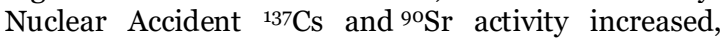
especially in the first days after the accident.

It is necessary to monitor activity concentrations of radionuclides, including radon in drinking water, especially for the radionuclides with the highest effective dose conversion factor in order to assess the equivalent annual effective dose.

Acknowledgement: The paper is a part of the research done within the institutional project 15.817.04.05A., funded by the Academy of Sciences of Moldova. Authors like to express their deepest gratitude the Radiation Protection Center of the National Centre of Public Health for the technical support.

\section{REFERENCES}

1. Government of the Republic of Ireland. (Apr. 15, 2016). S. I. No. 160 of 2016 European Union (Radioactive Substances in Drinking Water) Regulations.

Retrieved from:

https://www.fsai.ie/uploadedFiles/Legislation/Food_L egisation Links/Water/SI160_2016.pdf

Retrieved on: Jan. 11, 2017

2. Republica Moldova, Ministreul Sănătății. (27.02.2001.). Nr. o65334 Norme fundamentale de radioprotecţie. Cerinţe şi reguli igienice. (Republic of Moldova, Ministry of Health. (Feb. 27, 2001). No. 065334 Radioprotection fundamental norms. Hygienic requirements and rules.)

3. M. S. Al-Masri, R. Blackburn, "Radon-222 and related activities in surface waters of the English Lake District," Appl. Radiat. Isot, vol. 50, no. 6, pp. 1137-1143, Apr. 1999.

DOI: 10.1016/So969-8043(98)00135-3

4. K. Somlai et al., "Rn-222 concentrations of water in the Balaton Highland and in the southern part of Hungary, and the assessment of the resulting dose," Radiat. Meas, vol. 42, no. 3, pp. 491-495, Mar. 2007. DOI: $10.1016 /$ j.radmeas.2006.11.005

5. O. Baykara, M. Dogru, "Measurement of radon and uranium concentration in water and soil samples from East Anatolian Active Fault Systems (Turkey)," Radiat. Meas, vol. 41, no. 3, pp. 362, Mar. 2006.

DOI: $10.1016 /$ j.radmeas.2005.06.016

6. H. A. Khan, "Usefulness of radon measurements in earth sciences," Nucl. Tracks. Radiat. Meas, vol. 22, no. 1-4, pp. 355-364, 1993. DOI: 10.1016/0969-8078(93)90085-I

7. H. Alonso et al., "Radon in groundwater of the northeastern Gran Canaria aquifer." Water, vol. 7, no. 6, pp. 2575-2590, May 2015. DOI: $10.3390 /$ w7062575 
8. Y. Fakhri et al., "Effective dose of radon 222 bottled water in different age groups humans: Bandar Abbas City, Iran," Glob. J. Health Sci., vol. 8, no. 2, pp. 64-71, Feb 2016.

DOI: 10.5539/gjhs.v8n2p64

PMid: 26383192

PMCID: PMC4803962

9. Guidelines for drinking-water quality, Vol. 1: Recommendations, 3rd ed. World Health Organization, Geneva, 2004.

Retrieved from:

http://www.who.int/water sanitation health/dwq/GD

WQ2004web.pdf

Retrieved on: Dec. 15, 2016

10. Y. Fakhri et al., "Effective dose of radon 222 of the tap water in children and adults people; Minab City, Iran," Glob. J. Health Sci., vol. 8, no. 4, pp. 234-243, Apr. 2016.

DOI: $10.5539 /$ gjhs.v8n4p234

PMid: 26573047

PMCid: PMC4873584

11. "Sources and effects of ionizing Radiation," United Nations Scientific Committee on the Effects of Atomic Radiation, New York, (NY), USA, Rep. 46 (A/55/46), 2000

Retrieved from:

http://www.unscear.org/docs/publications/2000/UNS CEAR 2000 Report Vol.I.pdf

Retrieved on: Jan. 12, 2017

12. Home Buyer's and Seller's Guide to Radon, United States Environmental Protection Agency, Washington, (DC), USA, 2006.

Retrieved from: https://www.epa.gov/radon Retrieved on: Jan. 12, 2017

13. H. Al Zabadi et al., "Exposure assessment of radon in the drinking water supplies: A descriptive study in Palestine," BMC Res. Notes, vol. 5, no. 29, pp. 1-8, Jan. 2012.

DOI: $10.1186 / 1756-0500-5-29$

14. W. Yun-Yun et al., "Radon concentrations in drinking water in Beijing City, China and contribution to radiation dose." Int. J. Environ. Res. Public Health, vol. 11, no. 11, pp. 11121-11131, Oct. 2014.

DOI: $10.3390 /$ ijerph111111121

PMid: 25350007

PMCid: PMC4245603

15. H. Bem et al., "Radon (222Rn) in underground drinking water supplies of the Southern Greater Poland Region," J. Radioanal. Nucl. Chem., vol. 299, no. 3, pp. 13071312, Jan. 2014.

DOI: 10.1007/s10967-013-2912-1

PMid: 26224959

PMCid: PMC4514460

16. Toxicologie de l'environnement bâti. Qu'est-ce que le radon? Etat de Gèneve, Gèneve, Suisse. (Toxicology of the built environment. What is radon? Canton of Geneva, Geneva, Switzerland.) Retrieved from:

http://etat.geneve.ch/dt/toxicologie-pollutions/radon747-3699\%208414.html Retrieved on: Aug. 29, 2016

17. R. L. Rudnick, S. Gao, "Composition of the continental crust," in Treatise on Geochemistry, vol. 3, R. L. Rudnick, H. D. Holand, K. K. Turekian, Eds., 1st ed., Amsterdam, Netherlands: Elsevier, 2003, ch. 1, pp. 1-64.

DOI: 10.1016/Bo-08-043751-6/o3016-4
18. J. D. Ayotte, S. M. Flanagan, W. S. Morrow, "Occurrence of uranium and ${ }^{222}$ Radon in glacial and bedrock aquifers in the northern United States, 1993-2003," U.S. Geological Survey Scientific Investigations Report, Washington, (DC), USA, Rep. 2007-5037, 2007.

Retrieved from:

https://pubs.usgs.gov/sir/2007/5037/pdf/SIR20075037.pdf

Retrieved on: Jan. 13, 2017

19. R. B. Wanty, R. Schoen, "A review of the chemical processes affecting the mobility of radionuclides in natural waters, with applications," in Field Studies of radon in rocks, soils, and water, vol. 1 , L. C. S. Gundersen, R. B. Wanty, Eds., 1st ed., Washington, (DC), USA: U.S. Government Printing Office, 1991, ch. 2, sec. 1, pp. 183-192.

Retrieved from:

https://pubs.usgs.gov/bul/1971/report.pdf Retrieved on: Jan. 12, 2017.

20. H. B. Jung et al., "Redox behavior of uranium at the nanoporous aluminum oxide-water interface: Implications for uranium remediation," Environ. Sci. Technol., vol. 46, no. 13, pp. 7301-7309, Jun. 2012. DOI: $10.1021 /$ es2044163

PMid: 22681597

21. Radiation Effects and Sources, United Nations Effects and Programme, Austria, 2016.

Retrieved from:

http://www.ansto.gov.au/cs/groups/corporate/docume nts/document/mdaw/mdu2/ edisp/acs106214.pdf Retrieved on: Dec. 18, 2016

22. V. Pintilie et al., "Natural radioactivity in drinking water from Galati and Vrancea areas, Romania," Radiation and Applications, vol. 1, no. 3, pp. 165-170, Dec. 2016. DOI: 10.21175/radj.2016.03.031

23. C. Cosma, T. Jurcut, Radonul si mediul înconjurător, Cluj-Napoca, Romania: Editura Dacia, 1996. (C. Cosma, T. Jurcut, "Radon and environment," Cluj-Napoca, Romania: Dacia Publishing House, 1996.)

24. R. B. Wanty, E. P. Lawrence, L. C. S. Gundersen, "A theoretical model for the flux of radon from rock to ground water," Geol. Soc. Am. Spec. Pap., vol. 271, pp. 73-78, Apr. 1992. DOI: $10.1130 /$ SPE271-p73

25. L. Corețchi și colab., "Monitoringul concentrațiilor de Radon pe teritoriul Republicii Moldova." Sănătate Publică, Economie și Management în Medicină, vol. 3 no. 42, pp. 19-23, 2012. (L. Corețchi et al., "Monitoring of Radon concentrations in the Republic of Moldova territory." Public Health, Economics and Management in Medicine, vol. 3, no. 42, pp. 19-23, 2012.)

Retrieved from:

http://publichealth.md/uploads/docs/reviste/CM3 42 2012.pdf Retrieved on: Jan. 15, 2017

26. The Council of European Union. (Dec. 5, 2013). Council Directive 2013/59/EURATOM laying down basic safety standards for protection against the dangers arising from exposure to ionising radiation, and repealing Directives 89/618/Euratom, 90/641/Euratom, 96/29/Euratom, 97/43/Euratom and 2003/122/Euratom.

Retrieved from:

http://eur-lex.europa.eu/legalcontent/EN/TXT/PDF/?uri=CELEX:32013L0059\&fro $\mathrm{m}=\mathrm{EN}$

Retrieved on: Dec. 16, 2016 